\title{
ABET Program Educational Objectives Proposed Assessment Method
}

\author{
Taan ElAli* \\ College of Aeronautics, Engineering Program, Embry Riddle Aeronautical University-Worldwide, Daytona \\ Beach, FL 32114, USA
}

*Corresponding Author: Taan ElAli, College of Aeronautics, Engineering Program, Embry Riddle Aeronautical University-Worldwide, Daytona Beach, FL 32114, USA.

\begin{abstract}
One of the foundations for ABET accreditation process is that the program seeking accreditation establishes the program educational objectives. Those objectives are wat the program graduate is expected to demonstrate after graduation in the industry and in the field of graduate education. The program must establish a process for the evaluation of the program educational objectives. This is an essential part of the continuous improvement process required by ABET. Once the program educational objectives are established in consultation with the program constituencies and the advisory board, they will be mapped to the program student outcomes and the institution mission statement. In this paper we will show a sample process of how this mechanism works.
\end{abstract}

Keywords: ABET, Engineering Curriculum, Assessment, Course Outcomes Portfolio, Course Outcomes, Program Outcomes, Program Educational Objectives, Student Outcomes, Student Learning Outcomes

\section{INTRODUCTION AND LITERATURE REVIEW}

ABET accreditation is very important award that every institution in the USA and abroad would love to seek and the program educational objectives continuous improvement plan should be carefully constructed and executed [1,2,3].

Mapping the student learning outcomes to the program educational objectives is a complex process $[4,5$, and 6]. To improve the process of program educational objective assessment the idea of student portfolio has emerged [7, 8, 9, and 10].

In this paper, a new approach to program educational objectives assessment will be presented. This approach will establish a strong mapping between the program educational objectives and the student learning outcomes; it is an improvement on previous processes that were discussed in literature on this topic $[11,12,13,14$, and 15].

\section{THE PROCESS}

\subsection{Terms Used}

$\mathrm{CO}$

CACIC

SO

SOP

PEO

$\mathrm{AB}$

GSS

WSS

ES

SGSS

PGSS

\section{Course Outcomes}

Curriculum assessment and Continuous Improvement Committee

Student Outcomes

Student Outcomes Portfolio

Program Educational Objectives

Advisory Board

Graduating Senior Survey

Working Student Survey

Employer Survey

Student Graduate School Survey

Post Graduate Student Survey 
PEO are those objectives that are derived from the mission statement of the program by the

Program constituencies and AB. PEO are broad statements that describe the career and professional accomplishments that the program is preparing graduates to achieve.

\subsection{Rules}

All graduating seniors must fill a GSS

CACIC must send out two years after graduating our first batch of engineers the WSS, ES, SGSS, PGSS, then every year after.

\subsection{Steps}

Steps 2 to 7 are done every year, while steps 1 to 7 are done every four years.

- CACIC meets and discusses with AB the PEO and its relationship with SO and makes recommendations

- WSS, ES, SGSS, PGSS are gathered every year, starting 2 years after the graduation of the first batch

- GSS are gathered every semester

- The CACIC consults with $\mathrm{AB}$ and makes its recommendation to the chairperson

- The chairperson recommends to the dean any proposed changes

- The Dean decides on proposed changes

- Proposed changes implemented

\subsection{PEO Evaluation Diagram}

The evaluation process is given in Figure 1.

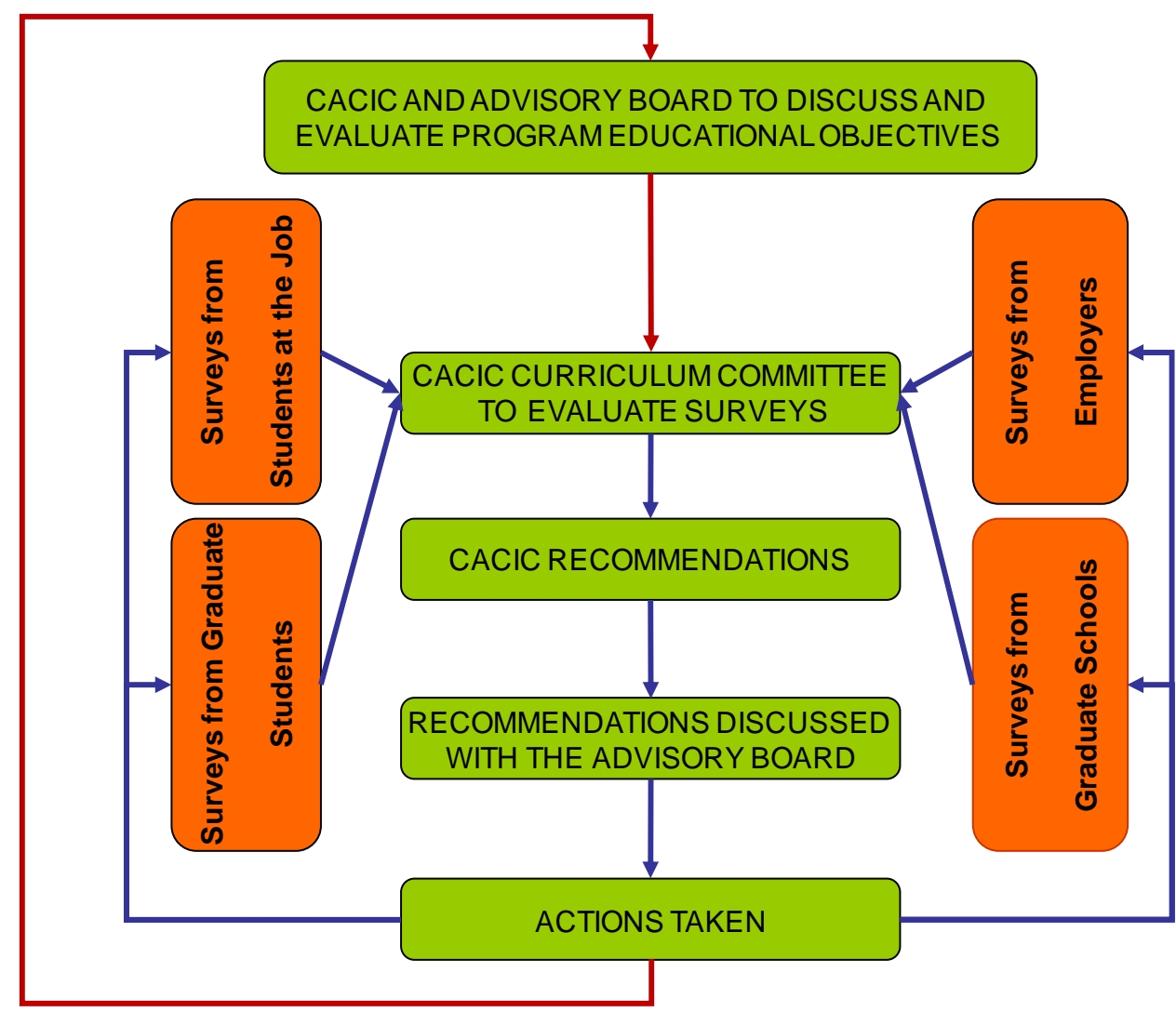

BLUE INNER LOOP EVALUATED ANNUALY RED OUTER LOOP EVALUATED EVEY 4 YEARS

Figure1 


\subsection{Sample Relation between Program Educational Objectives and Curricular Components}

This is shown in table 1 .

Table1

\begin{tabular}{|l|l|}
\hline Objective & Principal Relevant Curricular Components \\
\hline $\begin{array}{l}\text { Technically competent graduates for a } \\
\text { successful and productive career in the } \\
\text { engineering profession }\end{array}$ & $\begin{array}{l}\text { Balanced selection of basic and advanced courses in } \\
\text { hardware and software, significant mathematics/science } \\
\text { requirements. }\end{array}$ \\
\hline $\begin{array}{l}\text { Graduates who are capable of pursuing } \\
\text { postgraduate studies and research }\end{array}$ & $\begin{array}{l}\text { Balance of application and theory courses, independent } \\
\text { learning in projects and outside the classroom. }\end{array}$ \\
\hline $\begin{array}{l}\text { Graduates who can demonstrate their } \\
\text { effective communications and teamwork skills } \\
\text { in a diverse environment }\end{array}$ & $\begin{array}{l}\text { Major written documentation and oral presentation of } \\
\text { project; teamwork experience in projects; strong } \\
\text { educational component in communication skills. }\end{array}$ \\
\hline $\begin{array}{l}\text { Graduates with the desire for life-long } \\
\text { learning for the purpose of continuous } \\
\text { improvement }\end{array}$ & $\begin{array}{l}\text { Major project-based curriculum component that stimulates } \\
\text { inquiry and research supported by a strong set of common } \\
\text { basic engineering courses from different engineering } \\
\text { disciplines }\end{array}$ \\
\hline
\end{tabular}

\subsection{Sample Employer Survey}

The faculty and staff in the $\mathrm{xx}$ program at $\mathrm{xx}$ university would like to get your input regarding We appreciate your time for this will help us to improve our program and to produce graduates that you and us will be proud of.

Please fill in the following information electronically and return to xxxxx@xxxxx.edu. We appreciate your time and effort. Many thanks in advance.

Date:

Your name:

Company name:

Company address:

Do you think that the employee has adequate preparation for this job? (Yes/No) If no, do you have any suggestions that will allow us to improve our program? Please list them below:

How long has the employee been working at your firm?

Has the employee been promoted? (Yes/No)

\begin{tabular}{|c|c|c|c|c|c|}
\hline \multirow[t]{2}{*}{ The electrical engineering program at $\mathrm{xxx}$ was able } & \multicolumn{5}{|c|}{$\begin{array}{l}\text { Disagree or Agree Strongly } \\
\text { Disagree (1) } \\
\text { Strongly Agree (5) }\end{array}$} \\
\hline & 1 & 2 & 3 & 4 & 5 \\
\hline $\begin{array}{l}\text { To produce graduates with the necessary background and technical knowledge } \\
\text { for a successful career in xxx engineering. }\end{array}$ & & & & & \\
\hline To produce graduates who are able to compete and earn graduate degrees. & & & & & \\
\hline $\begin{array}{l}\text { To produce graduates who have developed effective communication and } \\
\text { teamwork skills. }\end{array}$ & & & & & \\
\hline $\begin{array}{l}\text { To produce graduates who have developed commitment to the ethical, } \\
\text { professional, and social responsibilities. }\end{array}$ & & & & & \\
\hline $\begin{array}{l}\text { To produce graduates who are well prepared at the fundamental level for life- } \\
\text { long learning in their xxx engineering career. }\end{array}$ & & & & & \\
\hline
\end{tabular}


Any other comments or suggestions?

\subsection{Sample Graduate School Survey}

The faculty and staff in the $\mathrm{xxx}$ Program at $\mathrm{xx}$ university are very interested to know about the progress of our graduate student, . We appreciate your time for this will help us to improve our xxx program and to produce graduates that you and us will be proud of.

Please fill in the following information electronically and return to xxxxx@xxx.edu

We appreciate your time and effort. Many thanks in advance.

Date:

Your Name:

Position:

Name of graduate school

Address:

Is the student making satisfactory progress toward graduation? Explain?

Is the student graduating as planned? (Yes/No)

How do you rank the student performance with other graduate students from different graduate schools?

Do you think the xxx program at xxx provided our student with adequate educational background for graduate studies? (Yes/No)

If no, what improvements do you suggest? Please list below:

Do you have any suggestions that will allow us to improve our program? Please list below:

\begin{tabular}{|c|c|c|c|c|c|}
\hline \multirow[t]{2}{*}{ The $\mathrm{xxx}$ program at $\mathrm{xxx}$ was able } & \multicolumn{5}{|c|}{$\begin{array}{l}\text { Disagree or Agree Strongly } \\
\text { Disagree (1) } \\
\text { Strongly Agree (5) }\end{array}$} \\
\hline & 1 & 2 & 3 & 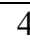 & 5 \\
\hline \multicolumn{6}{|l|}{$\begin{array}{l}\text { To produce graduates with the necessary background and technical } \\
\text { knowledge for a successful career in xxx engineering. }\end{array}$} \\
\hline \multicolumn{6}{|l|}{ To produce graduates who are able to compete and earn graduate degrees. } \\
\hline $\begin{array}{l}\text { To produce graduates who have developed effective communication and } \\
\text { teamwork skills. }\end{array}$ & & & & & \\
\hline
\end{tabular}


To produce graduates who have developed commitment to the ethical, professional, and social responsibilities.

To produce graduates who are well prepared at the fundamental level for life-long learning in their $\mathrm{xxx}$ engineering career.

Any other comments or suggestions?

\subsection{Sample Graduate Student Industry Survey}

The faculty, staff, and students in the xxx Program at xxx are very interested to know what are you currently doing and how the $\mathrm{xxx}$ Engineering degree from $\mathrm{xxx}$ has helped you to prepare for your current career.

Please fill in the following information electronically and return to xxx@xxx.edu We appreciate your time and effort. Many thanks in advance.

Date:

Your name:

Graduating date:

What is your title? Years in this position:

Did you get any promotions? (Yes/No) If yes, please explain

Are you involved in attending professional conferences? (Yes/No) If yes, how many in the last 2 years?

Do you have any suggestions that will allow us to improve our $\mathrm{xxx}$ engineering program? (Yes/No) , If yes, please list them below:

\begin{tabular}{|c|c|c|c|c|c|}
\hline \multirow[t]{2}{*}{ The $\mathrm{xxx}$ program at $\mathrm{xxx}$ was able } & \multicolumn{5}{|c|}{$\begin{array}{l}\text { Disagree or Agree Strongly } \\
\text { Disagree (1) } \\
\text { Strongly Agree (5) }\end{array}$} \\
\hline & 1 & 2 & 3 & 4 & 5 \\
\hline $\begin{array}{l}\text { To produce graduates with the necessary background and technical } \\
\text { knowledge for a successful career in xxx. }\end{array}$ & & & & & \\
\hline To produce graduates who are able to compete and earn graduate degrees. & & & & & \\
\hline $\begin{array}{l}\text { To produce graduates who have developed effective communication and } \\
\text { teamwork skills. }\end{array}$ & & & & & \\
\hline $\begin{array}{l}\text { To produce graduates who have developed commitment to the ethical, } \\
\text { professional, and social responsibilities. }\end{array}$ & & & & & \\
\hline $\begin{array}{l}\text { To produce graduates who are well prepared at the fundamental level for } \\
\text { life-long learning in their } \mathrm{xxx} \text { engineering career. }\end{array}$ & & & & & \\
\hline
\end{tabular}

Any other comments or suggestions?

\subsection{Sample Graduate Student University Survey}

The faculty, staff, and students in the xxx Engineering Program at xxx university are very interested to know what are you currently doing and how the $\mathrm{xxx}$ Engineering degree from $\mathrm{xxx}$ has helped you to prepare for your current career.

International Journal of Innovative Research in Electronics and Communications (IJIREC) $\quad$ Page | 5 
Please fill in the following information electronically and return to xxxxx@xxx.edu. We appreciate your time and effort. Many thanks in advance.

Date:

Your name:

Graduating date:

Graduate school you're attending

Address:

How is your progress toward graduation? Explain

Are you graduating as planned? (Yes/No)

Do you think the $\mathrm{xxx}$ engineering program at $\mathrm{xxx}$ provided you with adequate educational background for graduate studies? (Yes/No)

If not, what improvements do you suggest? Please list below:

Do you have any suggestions that will allow us to improve our electrical engineering program? Please list below:

How do you rank your performance with other graduate students from different graduate schools?

Are you involved in attending professional conferences? (Yes/No) If yes, how many in the last 3 years?

\begin{tabular}{|l|l|l|l|l|l|}
\hline \multirow{2}{*}{ The xxx engineering program at xxx was able } & \multicolumn{3}{l}{$\begin{array}{l}\text { Disagree or Agree Strongly } \\
\text { Disagree (1) } \\
\text { Strongly Agree (5) }\end{array}$} \\
\cline { 3 - 6 } & 1 & 2 & 3 & 4 & 5 \\
\hline $\begin{array}{l}\text { To produce graduates with the necessary background and technical } \\
\text { knowledge for a successful career in xxx engineering. }\end{array}$ & & & & \\
\hline To produce graduates who are able to compete and earn graduate degrees. & & & & & \\
\hline $\begin{array}{l}\text { To produce graduates who have developed effective communication and } \\
\text { teamwork skills. }\end{array}$ & & & & \\
\hline $\begin{array}{l}\text { To produce graduates who have developed commitment to the ethical, } \\
\text { professional, and social responsibilities. }\end{array}$ & & & & \\
\hline $\begin{array}{l}\text { To produce graduates who are well prepared at the fundamental level for } \\
\text { life-long learning in their xxx engineering career. }\end{array}$ & & & & & \\
\hline
\end{tabular}

Any other comments or suggestions? 


\section{REFERENCES}

[1] Decade of Assessment in Higher Education. T.W. Banta (ed.).Jossey-Bass, San Francisco 1993.

[2] Office of Institutional Research, Planning, and Assessment, Rose-Hulman Institute of Technology, http://www.rose-hulman.edu/IRA/IRA/index.html, 2000.

[3] Barrett, H.C. 1998. Strategic questions: What to consider when planning for electronic portfolios. Learning and Leading with Technology. 26(2): 6-13.

[4] Olds, B.M., and R.L. Miller, "An Assessment Matrix for Evaluating Engineering Programs," Journal of Engineering Education, vol. 87, no. 2, 1998, pp. 173-178.

[5] Ramsden, P. (1991), 'A performance indicator of teaching quality in higher education: the Course Experience Questionnaire', Studies in Higher Education, 16, 129-150.

[6] Loacker, G., and M. Mentkowski, “Creating a Culture Where Assessment Improves Learning,” in Making a Difference: Outcomes of a

[7] McGourty, J., C. Sebastian, and W. Swart. 1998. Developing a comprehensive assessment program for engineering education. Journal of Engineering Education. 87(4): 355-361.

[8] Olds, B.M., and R.L. Miller, "Using Portfolios to Assess a ChE Program," Chemical Engineering Education, vol. 33, no. 2, 1999, pp. 110-114.

[9] Rogers, G., and J.K. Sando. 1996. Stepping Ahead: An Assessment Plan Development Guide. Terre Haute: Rose-Hulman Institute of Technology.

[10] Rose Hulman Institute of Technology, RosE-Portfolio Demonstration, http://www.rose hulman.edu/ira/reps, (accessed May 30, 2001).

[11] Christy, A.D., and M.B. Lima. 1998. The use of student portfolios in engineering instruction. Journal of Engineering Education. 87(2): 143-148. 16 Journal of Engineering Education January 2003

[12] Olds, B.M., and R.L. Miller. 1997. Portfolio assessment: Measuring moving targets at an engineering school. NCA Quarterly. 71(4): 462-467

[13] Panitz, B. 1996. The student portfolio: A powerful assessment tool. ASEE Prism. March 1996: 24-29.

[14] Accreditation Board for Engineering and Technology, ABET Homepage, http://www.abet.org (20172018).

[15] Prosser, M., and Trigwell, K. (in press). 'Student evaluation of teaching and courses: student learning approaches and outcomes as criteria of validity', Contemporary Educational Psychology.

Citation: Taan ElAli, “ABET Program Educational Objectives Proposed Assessment Method." International Journal of Innovative Research in Electronics and Communications (IJIREC), 7(1), pp.1-7. http://dx.doi.org /10.20431/2349-4050.0701001

Copyright: (C) 2020 Authors this is an open-access article distributed under the terms of the Creative Commons Attribution License, which permits unrestricted use, distribution, and reproduction in any medium, provided the original author and source are credited. 